\title{
Autoantibody-mediated arthritis in the absence of C3 and activating Fcy receptors: C5 is activated by the coagulation cascade
}

\author{
Jennifer L Auger ${ }^{1}$, Stefanie Haasken ${ }^{1,2}$ and Bryce A Binstadt ${ }^{*}$
}

\begin{abstract}
Introduction: The effector functions of immunoglobulin $\mathrm{G}(\mathrm{lgG})$ are mediated by interaction of its Fc region with Fc receptors (FcyRs) and/or the complement system. The three main pathways of complement activation converge at C3. However, C3-independent pathways can activate C5 and other downstream complement components during IgG-initiated inflammatory responses. These C3-independent pathways of C5 activation are triggered by activating FcyRs in some systems or can be activated by factors of the coagulation cascade such as thrombin. Here we studied the interplay of $C 3, C 5$, and activating FcyRs in a model of spontaneous autoantibody-driven arthritis.

Methods: We utilized the K/BxN TCR transgenic mouse model of arthritis. We bred K/BXN mice bearing targeted or naturally-occurring mutations in one or more of the genes encoding complement components C3, C5, and FcR $\gamma$, the cytoplasmic signaling chain shared by the activating FcyRs. We measured arthritis development, the production of arthritogenic autoantibodies, T cell activation status and cytokine synthesis. In addition, we treated mice with anti-C5 monoclonal antibodies or with the thrombin inhibitor argatroban.

Results: We have previously shown that genetic deficiency of C5 protects $\mathrm{K} / \mathrm{BxN}$ mice from the development of arthritis. We found here that C3-deficient K/BxN mice developed arthritis equivalent in severity to C3-sufficient animals. Arthritis also developed normally in K/BxN mice lacking both C3 and FcR $\gamma$, but could be ameliorated in these animals by treatment with anti-C5 monoclonal antibody or by treatment with argatroban. Production of arthritogenic autoantibodies, T cell activation, and T cell cytokine production were not affected by the absence of C3, C5, and/or FCR $\gamma$.

Conclusions: In K/BxN mice, C5-dependent autoantibody-driven arthritis can occur in the genetic absence of both complement C3 and activating FcyRs. Our findings suggest that in this setting, thrombin activates C5 to provoke arthritis.
\end{abstract}

\section{Introduction}

The ability of immunoglobulin and immune complexes, including autoantibodies, to provoke inflammation stems from the interaction of the Fc portion of antibody molecules with one or both of two major effector pathways: Fc receptors and the complement system. The relative contributions of these two pathways vary among different disease states and experimental systems [1-3]. A more detailed understanding of the mechanisms by which autoantibodies engage Fc receptors and

\footnotetext{
* Correspondence: binstadt@umn.edu

'Center for Immunology and Department of Pediatrics, University of

Minnesota, 2101 6th Street SE, Minneapolis, MN 55414, USA

Full list of author information is available at the end of the article
}

complement to provoke pathology in a specific target tissue can permit a more tailored therapeutic intervention.

Fc $\gamma$ receptors (Fc $\gamma \mathrm{Rs}$ ) recognize immunoglobulin $\mathrm{G}$ (IgG) and transduce either activating or inhibitory intracellular signals. In the mouse, the activating Fc $\gamma$ Rs include Fc $\gamma$ RI, Fc $\gamma$ RIII, and Fc $\gamma$ RIV. The activating Fc $\gamma$ Rs share a common cytoplasmic signaling chain called FcR $\gamma$ (encoded by the Fcer $1 g$ gene) responsible for signal transduction. Mice also express the inhibitory receptor Fc $\gamma$ RIIB, whose cytoplasmic tail contains an inhibitory signaling motif. The outcome of an interaction of an Fc $\gamma$ R-expressing cell with an IgG-containing immune complex depends on the relative expression levels of the

\section{C) Biomed Central}


various activating and inhibitory Fc $\gamma$ Rs and also the IgG subtype (for which the various Fc $\gamma$ Rs have differing affinities) [4].

The complement system is activated by three primary pathways (classic, alternative, and mannose-binding-lectin), each consisting of a series of serine proteases. These three activation pathways converge at complement component C3. Cleavage of complement C3 produces a $\mathrm{C} 5$ convertase. These events result in the generation of anaphylatoxins (for example, C3a and C5a) and formation of the membrane attack complex (C5b-9), whose main functions are to recruit inflammatory cells and to mediate cellular lysis, respectively (Figure 1) $[5,6]$.

Several studies have pointed to the existence of additional, C3-independent mechanisms by which $\mathrm{C} 5$ can be activated to drive inflammatory responses (Figure 1). More than two decades ago, investigators described the existence of C5-C9-dependent immune hemolysis occurring in a C3-independent fashion [7,8]. More recently, studies of IgG-triggered acute lung injury revealed that, in C3-deficient mice, thrombin can act as a C5 convertase to generate C5a and mediate pathology [9]. Similar crosstalk between the complement system and coagulation systems has been identified in other model systems, including antiphospholipid antibody-induced and lipopolysaccharide (LPS)-induced fetal loss in mice $[10,11]$. An elegant in vitro study has recently confirmed that multiple serine proteases in the coagulation and fibrinolysis systems can cleave $\mathrm{C} 3$ and $\mathrm{C} 5$ to produce $\mathrm{C} 3 \mathrm{a}$ and C5a [12]. Interplay of Fc $\gamma$ Rs and the complement system also occurs, and several studies of IgG-initiated pathology have highlighted the existence of a C5a generation pathway that is triggered by activating Fc $\gamma R s$ [2,13-15]. Here, we investigated a possible contribution of C3- independent mechanisms of $\mathrm{C} 5$ activation in a mouse model of autoantibody-mediated arthritis.

$\mathrm{K} / \mathrm{BxN} \mathrm{T}$-cell receptor (TCR) transgenic mice spontaneously develop inflammatory arthritis due to combined $\mathrm{T}$ - and B-cell recognition of the self-antigen glucose-6phosphate isomerase (GPI) and production of high-titer anti-GPI IgG autoantibodies [16,17]. Arthritis can also be provoked by injecting serum from $\mathrm{K} / \mathrm{BxN}$ mice into normal mice [18]. Importantly, the requirements for complement and activating Fc $\gamma$ Rs differ between the K/ $\mathrm{BxN}$ TCR transgenic mice and its derivative, the serum transfer model, likely reflecting the several-fold higher concentration of anti-GPI autoantibodies in the spontaneous genetic model. The development of serum-transferred arthritis depends on both activating Fc $\gamma$ Rs and the alternative pathway of complement activation. Specifically, mice with targeted or naturally occurring mutations in the genes encoding factor $\mathrm{B}$ (of the alternative pathway), C3, C5, the C5a receptor (C5aR), and FcR $\gamma$ were protected from developing serum-transferred arthritis [19-21]. In contrast, we have shown that $\mathrm{K} / \mathrm{BxN}$ TCR transgenic mice lacking FcR $\gamma$ developed spontaneous arthritis equivalently to controls but that C5-deficient $\mathrm{K} / \mathrm{BxN}$ mice developed less severe arthritis than controls [22]. In addition, treating $\mathrm{K} / \mathrm{BxN}$ mice with anti-C5 monoclonal antibody reduced their arthritis severity [22]. Those findings led us to investigate which of the upstream C5-activation pathways drives arthritis in $\mathrm{K} / \mathrm{BxN}$ mice.

\section{Materials and methods \\ Mice}

KRN TCR transgenic mice on the C57BL/6 (B6) background [16] were a gift from Diane Mathis and Christophe Benoist (Harvard Medical School, Boston, MA,

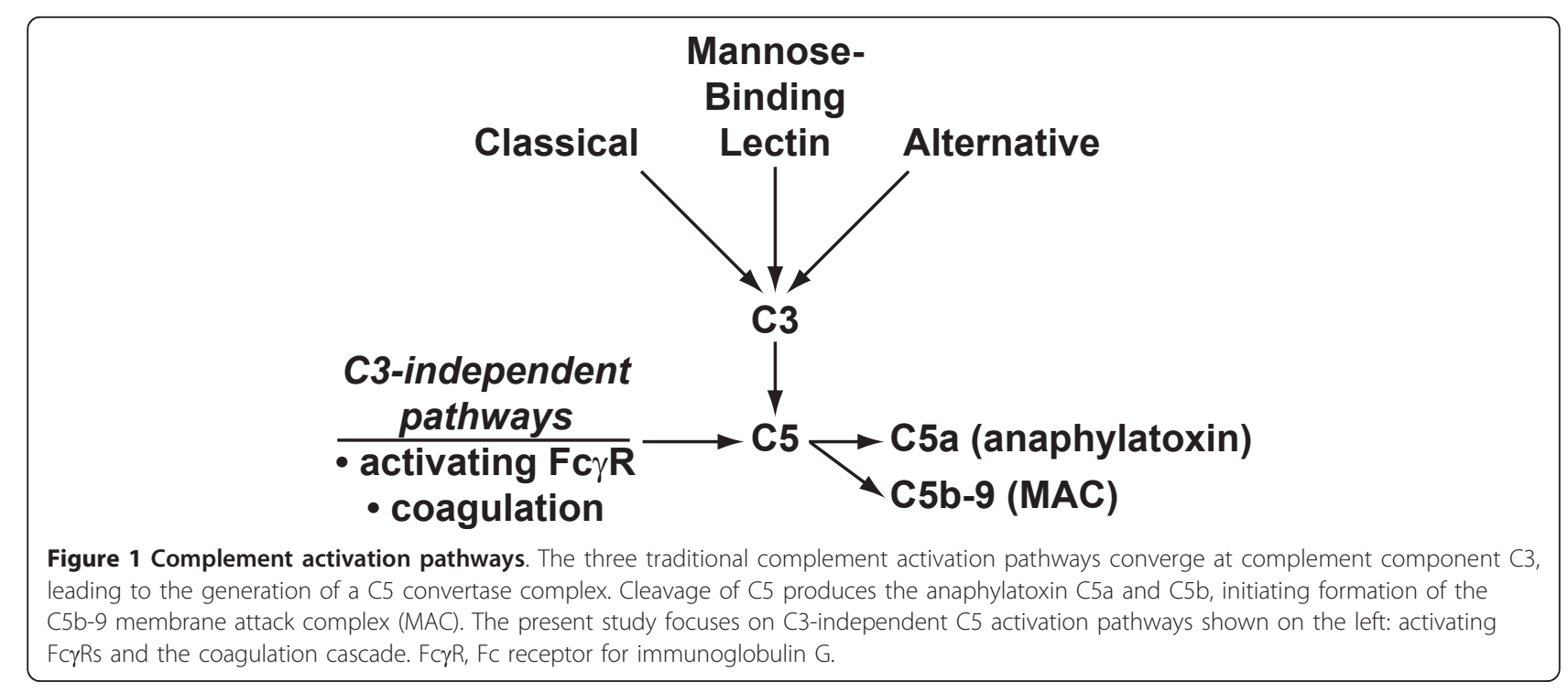


USA) and the Institut de Génétique et de Biologie Moléculaire et Cellulaire (Strasbourg, France). C5-deficient B6 mice congenic for the non-obese diabetic (NOD)derived $H c$ allele (encoding non-functional C5) $[22,23]$ and $\mathrm{B} 6$ mice congenic for $\mathrm{H}-2^{\mathrm{g} 7}$ (B6.g7) were also a gift from Mathis and Benoist; I- $\mathrm{A}^{\mathrm{g} 7}$ is the mouse major histocompatibility complex (MHC) class II molecule that presents GPI-derived peptides to activate KRN TCRexpressing $\mathrm{T}$ cells. C3-deficient mice on the B6 background [24] were a gift from Michael Carroll (Harvard Medical School). FcR $\gamma$ (Fcerlg)-deficient mice on the B6 background [25] were purchased from Taconic (Hudson, NY, USA).

The C3-, C5-, FcR $\gamma$-, and double-deficient 'K/BxN' lines used in this study were created by breeding mice bearing the appropriate knockout allele(s) on the B6 background to KRN/B6 mice and also to B6.g7 congenic mice. The MHC $(H 2)$ is the only NOD-derived genetic region that the $\mathrm{B} 6 . \mathrm{g} 7$ mice retain; to simplify nomenclature, however, we refer to the mice as ' $\mathrm{K} / \mathrm{BxN}$ ' throughout this study as we have previously [22]. Because C3 and the $H 2$ complex both reside on mouse chromosome 17 , a spontaneous chromosomal recombination event was necessary to generate C3-deficient B6.g7 congenic mice. Genotyping of mice was performed by standard polymerase chain reactions. Mice were bred in specific pathogen-free colonies under protocols approved by the University of Minnesota Institutional Animal Care and Use Committee.

\section{Antibodies}

Anti-C5 monoclonal antibodies were derived from the BB5.1 hybridoma, a gift from Brigitta Stockinger (MRC National Institute for Medical Research, London, UK) [26]. Antibodies used for flow cytometry included antiCD3 (clone 71A2), anti-CD44 (clone IM7), anti-CD62L (clone MEL-14), anti-interleukin-17 (anti-IL-17) (clone eBiol7B7), and anti-interferon-gamma (anti-IFN $\gamma$ ) (clone XMG1.2) from eBioscience (San Diego, CA, USA) and anti-CD4 (clone RM4-5) and anti-VB6 (clone RR4-7) from BD Pharmingen (San Diego, CA, USA).

Assessment of arthritis, anti-C5 antibody treatment, antiGPI titers, histology, and immunohistochemistry

Assessment of arthritis severity by clinical score and ankle thickening, treatment with anti-C5 antibody, determination of anti-GPI IgG titers by enzyme-linked immunosorbent assay, histological analysis, and immunohistochemistry for C3 and IgG were performed as described [22]. For detection of prothrombin, histologic sections of mouse liver were first blocked by using the avidin/biotin blocking kit (Invitrogen Corporation, Carlsbad, CA, USA). Primary antibodies then were added at a dilution of 1:20, in accordance with a prior report [9]. The primary antibodies were goat polyclonal IgG anti-thrombin (K20) or normal goat IgG (both from Santa Cruz Biotechnology, Inc., Santa Cruz, CA, USA). The primary antibodies were detected by secondary staining with biotin-coupled donkey anti-goat IgG diluted 1:2,000 (Santa Cruz Biotechnology, Inc.) followed by application of ImmPACT DAB peroxidase substrate with the $A B C$ peroxidase kit (Vector Laboratories, Burlingame, CA, USA).

\section{Flow cytometry}

Intracellular cytokine staining was performed in accordance with the instructions of the manufacturer (eBioscience). Flow cytometry was performed by using a FACSCalibur and an LSRII (BD Biosciences, San Jose, CA, USA), and cells were analyzed by using FlowJo V7.6 software (Tree Star, Inc., Ashland, OR, USA).

\section{Argatroban treatment}

Argatroban (Sigma-Aldrich, St. Louis, MO, USA) was dissolved in dimethyl sulfoxide (DMSO) and injected intraperitoneally into mice at a dose of $9 \mathrm{mg} / \mathrm{kg}$ daily or five days per week fromthe ages of 3 to 6 weeks $[27,28]$. No differences were observed between those mice receiving argatroban daily and those receiving it five days per week, so the results were pooled for analysis. The vehicle control-treated animals received DMSO intraperitoneally.

\section{Results and Discussion}

We recently reported that $\mathrm{K} / \mathrm{BxN} \mathrm{TCR}$ transgenic mice genetically lacking $\mathrm{C} 5$ or treated with anti-C5 monoclonal antibodies developed less severe arthritis than control animals [22]. To determine which of the upstream complement activation pathways were involved in arthritogenesis, we first investigated complement component $\mathrm{C} 3$, the convergence point for the three primary complement activation pathways and the component immediately upstream of $\mathrm{C} 5$. We bred $\mathrm{K} / \mathrm{BxN}$ mice with a targeted deletion in the $C 3$ gene. In agreement with a recent report, we observed that $\mathrm{C} 3$-deficient $\mathrm{K} / \mathrm{BxN}$ mice developed arthritis equivalently to littermate controls (Figure 2) [29]. This finding suggested that a nontraditional, C3-independent pathway of C5 activation was at work in these mice.

Several reports have demonstrated that engagement of activating Fc $\gamma$ Rs can trigger C5a production, even in the absence of C3 [2,13-15]. We therefore hypothesized that, in $\mathrm{C} 3$-deficient $\mathrm{K} / \mathrm{BxN}$ mice, the absence of activating Fc $\gamma$ Rs would impair C5 production and lead to less severe arthritis. To test this hypothesis, we bred $\mathrm{K} / \mathrm{BxN}$ mice genetically lacking both $\mathrm{C} 3$ and FcR $\gamma$, the cytoplasmic signaling chain shared by the activating FcyRs. Surprisingly, the $\mathrm{C} 3 / \mathrm{FcR} \gamma$-double-deficient $\mathrm{K} / \mathrm{BxN}$ mice 

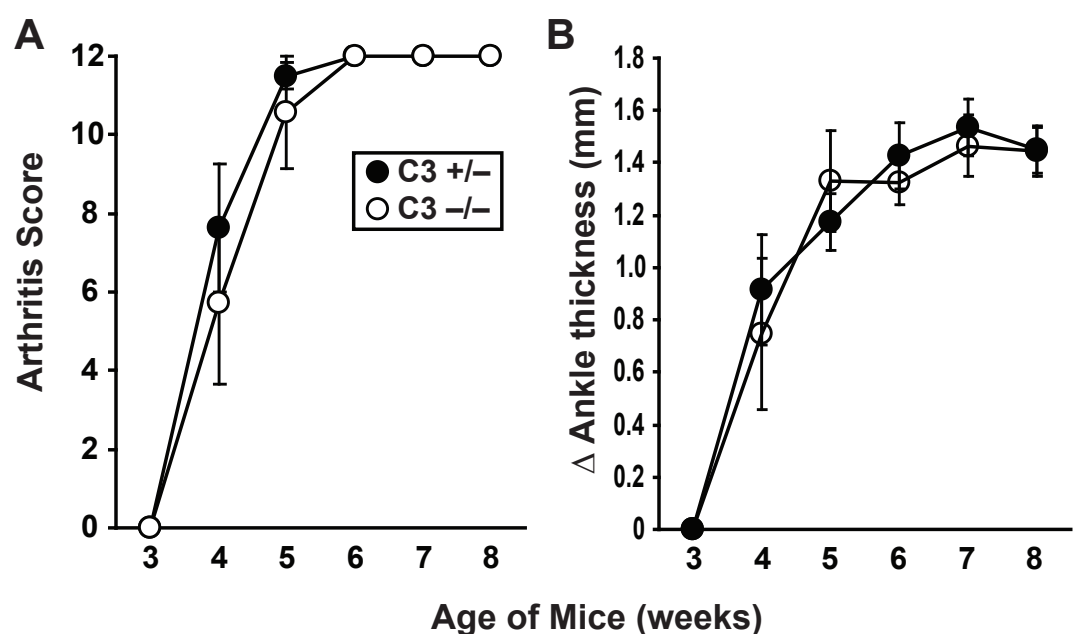

Figure 2 Complement C3 deficiency has no effect on arthritis in $\mathrm{K} / \mathrm{BxN}$ mice. The development of arthritis in $\mathrm{K} / \mathrm{BxN} \mathrm{T}$-cell receptor transgenic mice with a targeted deletion of C3 (open circles, $n=7$ mice) and C3-sufficient littermate controls (filled circles, $n=8$ ) was assessed by arthritis score (a) and ankle thickening (b). Data are mean \pm standard error of the mean. There are no statistically significant differences at any of the time points.

developed arthritis of equivalent severity to controls (Figure 3a). As expected, immunofluorescent staining of joint sections from the $\mathrm{C} 3 / \mathrm{FcR} \gamma$-deficient $\mathrm{K} / \mathrm{BxN}$ mice revealed IgG deposition similar to controls, but no C3 (Additional file 1a). Treatment of the $\mathrm{C} 3 / \mathrm{FcR} \gamma$-deficient
$\mathrm{K} / \mathrm{BxN}$ mice with anti-C5 monoclonal antibody reduced their arthritis severity (Figure 3a). Considered together, these findings indicate that, in the genetic absence of $\mathrm{C} 3$, arthritis in $\mathrm{K} / \mathrm{BxN}$ mice can be mediated by an FcR $\gamma$-independent $\mathrm{C} 5$ activation pathway.
A
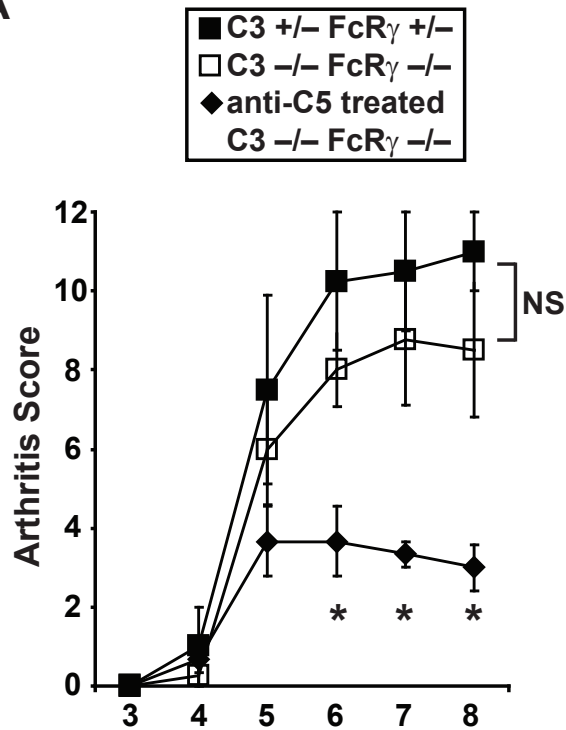

B
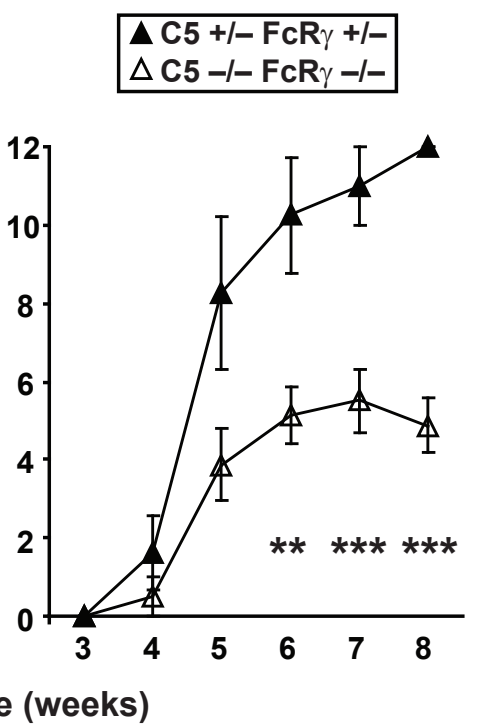

Figure 3 C5-mediated arthritis in K/BxN mice occurs in the absence of C3 and FcR $\gamma$. (a) Null alleles of C3 and Fcerlg (encoding FcR $\gamma$ ) were bred into the K/BXN mouse system. The development of arthritis was assessed in C3/FcR $\gamma$-deficient K/BxN mice bearing homozygous null alleles at both loci (open squares, $n=4$ ) and in littermate controls expressing one wild-type allele at each locus (filled squares, $n=4$ ). Data are mean \pm standard error of the mean (SEM); there are no statistical differences at any of the time points for these two groups. Treatment of the C3/FcR $y$ deficient K/BxN mice with anti-C5 antibody reduced arthritis severity (filled diamonds, $n=3$ ); ${ }^{*} P<0.05$ for the anti-C5 antibody-treated C3/FcR $\gamma$ deficient mice compared with untreated C3/FcR -deficient mice. (b) A naturally occurring null allele of Hc (encoding C5) and the targeted null allele of Fcerlg were bred into K/BxN mice. The development of arthritis was assessed in C5/FcR $\gamma$-deficient K/BxN mice (open triangles, $n=8$ ) and in littermate controls with one wild-type allele at each locus (filled triangles, $n=8$ ). Data are mean $\pm \mathrm{SEM}$; ${ }^{* *} P<0.01$; ${ }^{* * *} P<0.001$. FCR $\gamma$, the cytoplasmic signaling chain shared by activating Fc receptors for immunoglobulin G; NS, not significant. 
Consistent with our prior report that arthritis in $\mathrm{K} /$ BxN mice depends on C5 but not FcR $\gamma$ [22], we found that $\mathrm{K} / \mathrm{BxN}$ mice lacking both $\mathrm{C} 5$ and $\mathrm{FcR} \gamma$ developed less severe arthritis than controls (Figure $3 \mathrm{~b}$ ). In the ankles of these $\mathrm{C} 5 / \mathrm{FcR} \gamma$-deficient $\mathrm{K} / \mathrm{BxN}$ mice, deposition of both IgG and C3 was detectable, suggesting that C3 deposition can still occur in the absence of C5 and despite the less severe inflammatory response in these joints (Additional file 1b). The fact that the C5/FcR $\gamma$ deficient mice developed some arthritis, albeit attenuated, suggests that other minor pathogenic effector mechanisms are still operational in these mice; candidate pathways include recognition of IgG immune complexes by upstream complement components and their receptors (for example, $\mathrm{C} 1 \mathrm{qR}(\mathrm{P}) / \mathrm{CD} 93$ [30]), the proinflammatory activity of $\mathrm{C} 3 \mathrm{a}[6]$, and pathogenic effector T cells.

We performed additional studies to determine how C5 deficiency interferes with arthritogenesis in $\mathrm{K} / \mathrm{BxN}$ mice. We found that the production of anti-GPI autoantibodies was unimpaired in the C3-deficient, C3/FcR $\gamma$-deficient, and $\mathrm{C} 5 / \mathrm{FcR} \gamma$-deficient $\mathrm{K} / \mathrm{BxN}$ mice (Figure 4). C5a was also recently shown to drive $\mathrm{T}$ helper 17 (Th17) cell differentiation in another murine arthritis model [31]. Th17 cells are known to be involved in the pathogenesis of arthritis in the $\mathrm{K} / \mathrm{BxN}$ system [32,33]. We found, however, that $\mathrm{T}$-cell activation as determined by high expression of CD44 and low expression of CD62L (Figure 5a) and the frequency of CD $4^{+} \mathrm{T}$ cells producing the cytokines IFN $\gamma$ or IL-17 (Figure $5 \mathrm{~b}$ ) were unaltered in the $\mathrm{C} 5 / \mathrm{FcR} \gamma$-deficient $\mathrm{K} / \mathrm{BxN}$ mice relative to controls. Collectively, our findings indicate that the $\mathrm{T}$ cell- and B cell-dependent events culminating in autoantibody production and pro-inflammatory cytokine production are not impacted by deficiency of C3, C5, and/ or FcR $\gamma$ and suggest that $\mathrm{C} 5$ drives arthritis in $\mathrm{K} / \mathrm{BxN}$ mice via downstream effector mechanisms. Given the requirement of the $\mathrm{C} 5 \mathrm{aR}$ but not the terminal complement components (C6-C9) for serum-transferred arthritis [20], it is most logical that it is the interaction of C5a with $\mathrm{C} 5 \mathrm{aR}$ that drives arthritis in $\mathrm{K} / \mathrm{BxN}$ mice, a hypothesis that could be tested by generating C5aR-deficient $\mathrm{K} / \mathrm{BxN}$ mice. Next, we investigated how $\mathrm{C} 5$ was being activated in the absence of $\mathrm{C} 3$ and activating Fc $\gamma$ Rs.

Multiple lines of evidence point to molecular communications between the coagulation and complement cascades, both of which contain numerous serine proteases. Administration of the anticoagulant heparin blocked antiphospholipid antibody-induced complement activation and pregnancy loss in a mouse model [10]. Similarly, LPS increased the expression of the membranebound prothrombinase FGL2, which can cleave C5 and which also has been linked mechanistically to LPSinduced abortions in mice $[11,34]$. In mice lacking C3, the expression of prothrombin was upregulated, and treatment of mice with anti-thrombin III blocked IgGinduced C5-dependent lung injury [9]. We verified that the expression level of prothrombin was increased in the liver of $\mathrm{C} 3$-deficient mice relative to control mice (Additional file 2). In keeping with this finding, treatment of C3-deficient/FcR $\gamma$-deficient $\mathrm{K} / \mathrm{BxN}$ mice with the thrombin inhibitor argatroban led to reduced arthritis severity, and discontinuation of the argatroban was temporally associated with the re-emergence of arthritis (Figure 6). We are currently investigating longer-acting compounds to determine whether thrombin inhibition acts primarily to reduce arthritis severity or to delay the onset of arthritis in this model. Thus, the generation of $\mathrm{C} 5$ in the absence of $\mathrm{C} 3$ and activating Fc $\gamma$ Rs in $\mathrm{K} / \mathrm{BxN}$ mice appears to be mediated by thrombin or related serine proteases of the coagulation cascade.
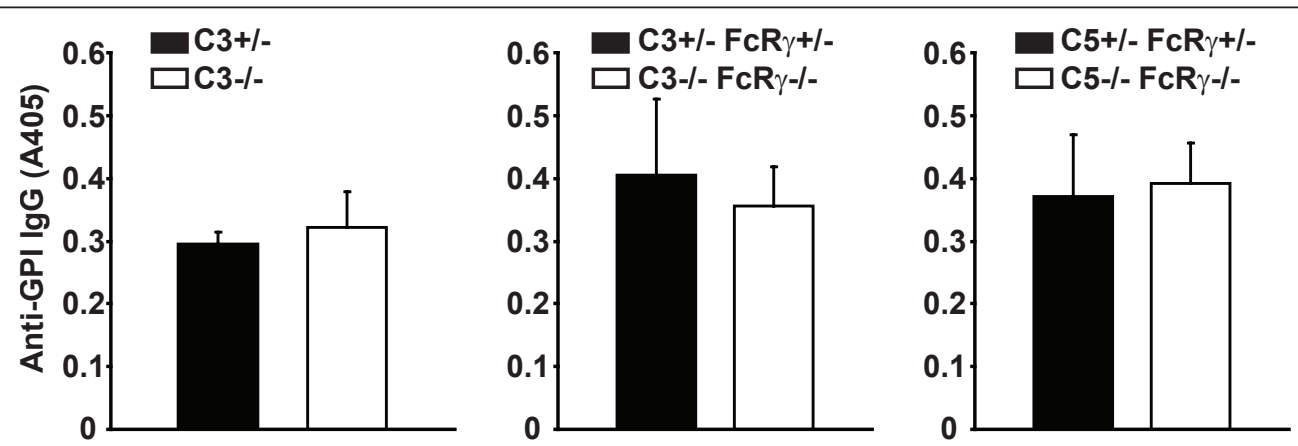

Figure 4 Absence of $\mathbf{C} 3, \mathbf{C} 5$, and FcR $\gamma$ does not impact autoantibody production in K/BxN mice. Serum levels of anti-GPI lgG were determined in C3-deficient K/BxN mice and controls (left panel), C3/FCRy-deficient K/BxN mice and controls (middle panel), and C5/FCR deficient K/BxN mice and controls (right panel). Control animals are indicated by filled bars and knockout mice by open bars. A405 indicates absorbance in the enzyme-linked immunosorbent assay. Data are mean \pm standard error of the mean. There are no statistically significant differences between the anti-GPI levels. FcR $\gamma$, the cytoplasmic signaling chain shared by activating Fc receptors for immunoglobulin G; GPI, glucose-6-phosphate isomerase; lgG, immunoglobulin G. 


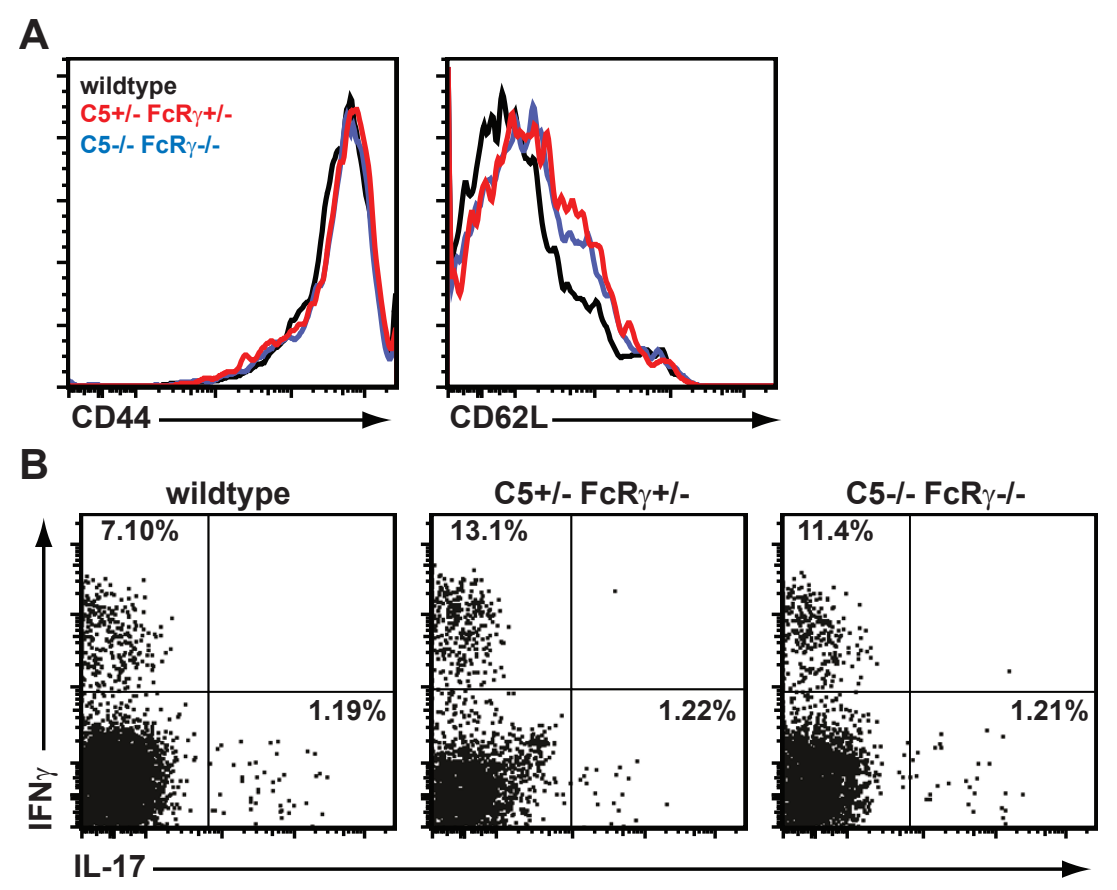

Figure 5 T-cell activation and cytokine production are not affected by $\mathrm{C} 5$ and FcR $\gamma$ deficiency in K/BxN mice. (a) The plots depict cell surface expression of $\mathrm{CD} 44$ and $\mathrm{CD} 62 \mathrm{~L}$ on $\mathrm{CD}^{+} \mathrm{CD}^{+} \vee \beta 6^{+}$-gated splenocytes from the indicated mice. (b) Intracellular expression of the cytokines interleukin-17 (IL-17) and interferon-gamma (IFN $\gamma$ ) was detected in $\mathrm{CD}^{+} \mathrm{CD}^{+} \vee \mathrm{V} \beta 6^{+}$splenocytes from the indicated mice. $V \beta 6$ is the TCR $\beta$ chain encoded by the KRN TCR transgene. Data are representative of two to six mice per group in three independent experiments. TCR, Tcell receptor.

Whether C3-independent pathways of C5 activation contribute to pathology in wild-type mice or only in the setting of genetic C3 deficiency is important for understanding the relevance of these pathways to human diseases. For instance, heparin was effective in reducing antiphospholipid antibody-induced fetal loss in wild-type mice by blocking C5a generation [10]. Similarly, treatment with the thrombin inhibitor polyethyleneglycolhirudin (PEG-hirudin) decreased the severity of collagen-induced arthritis in mice, although this was attributed to reductions in intra-articular fibrin deposition rather than to effects on complement activation [35]. In
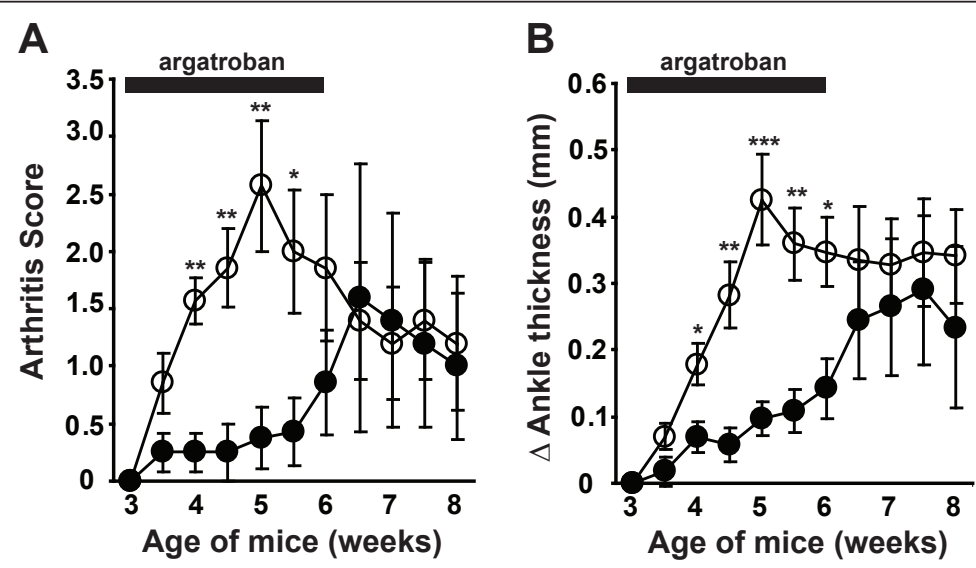

Figure 6 Thrombin inhibition ameliorates arthritis in C3/FcR $\gamma$-deficient K/BxN mice. K/BxN mice lacking C3 and FcR were treated with the thrombin inhibitor argatroban (filled circles) or vehicle control (open circles) from 3 to 6 weeks of age. Treatment was then stopped. The development of arthritis was determined by arthritis score (a) and twice weekly ankle measurements (b). Data plotted are mean \pm standard error of the mean and represent seven or eight mice per group compiled from three independent experiments. ${ }^{*} P<0.05$, ${ }^{* *} P<0.005$, ${ }^{* * *} P<$ 0.001. FcR $\gamma$, the cytoplasmic signaling chain shared by activating Fc receptors for immunoglobulin $\mathrm{G}$. 
contrast, in the IgG-mediated lung injury model, the effect of the anticoagulants anti-thrombin III and hirduin in reducing lung pathology was evident only in C3deficient animals, leading those investigators to speculate that genetic deficiency in C3 leads to upregulation of thrombin as a compensatory mechanism to allow C5 activation via a non-traditional pathway [9]. Similarly, we observed no effect of argatroban on arthritis severity in $\mathrm{C} 3$-sufficient $\mathrm{K} / \mathrm{BxN}$ mice (data not shown), but we are currently exploring longer-acting thrombin inhibitors. Thus, the contribution of the coagulation cascade to $\mathrm{C} 5$ activation might vary depending on the disease model. In addition, a recent report suggests that, in vitro, thrombin cleaves $\mathrm{C} 5$ at a site different from that cleaved by $\mathrm{C} 5$ convertase, leading to the generation of novel intermediates [36]. Understanding whether these intermediates are also generated in vivo and, if so, how they affect inflammation will be essential next steps.

How IgG antibodies activate thrombin in the absence of activating Fc $\gamma$ Rs and C3 remains an open and important question. Since thrombin activation by IgG has been observed in multiple autoantibody-dependent models, it is not likely that the antigenic specificity is critical. It seems more likely that other IgG-interacting molecules (for example, complement C1q or the neonatal Fc receptor) could be at play. Alternatively, antibody fragments with direct prothrombinase catalytic activity have been described [37].

From a clinical perspective, monoclonal antibody reagents designed to interfere with $\mathrm{C} 5$ activation systemically or locally (for example, in the synovium) might be effective treatments for inflammatory arthritis (Figure 3a) $[22,38,39]$. Our findings suggest that agents designed to interfere with non-traditional $\mathrm{C} 5$ activation pathways such as the coagulation cascade might also prove beneficial for treating inflammatory arthritis in certain settings.

\section{Conclusions}

The key finding of this study is that autoantibodymediated arthritis in $\mathrm{K} / \mathrm{BxN}$ mice can occur via a $\mathrm{C} 5$ activation pathway that requires neither $\mathrm{C} 3$ nor activating Fc $\gamma$ Rs, the two main effector mechanisms of IgG molecules. Genetic deficiency of C3, C5, and/or FcR $\gamma$ did not affect $\mathrm{T}$-cell activation or autoantibody production, indicating that the pro-arthritogenic activity of $\mathrm{C} 5$ is mediated by its conventional effector mechanisms (likely C5a production). Our data further suggest that thrombin or related proteases of the coagulation cascade mediate $\mathrm{C} 5$ activation in the absence of $\mathrm{C} 3$ and $\mathrm{FcR} \gamma$. Understanding how novel pathways of complement activation contribute to autoantibody-mediated arthritis and other inflammatory disorders is expected to lead to new therapeutic approaches.

\section{Additional material}

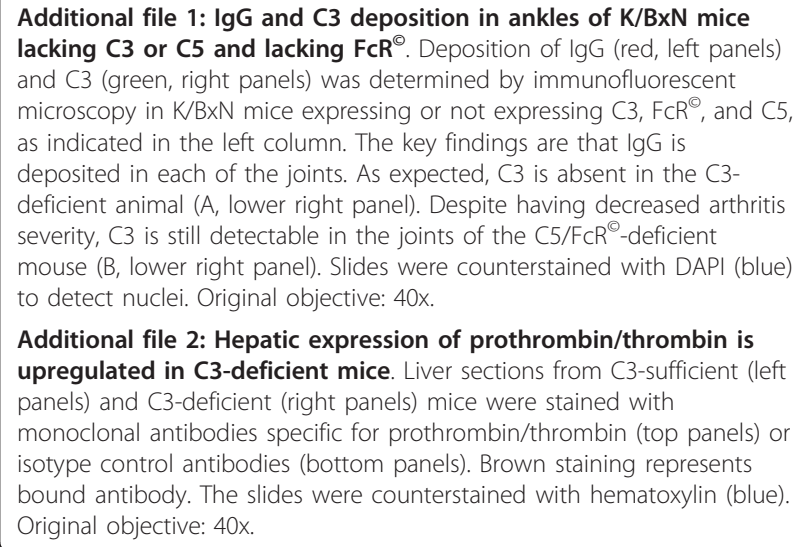

Additional file 2: Hepatic expression of prothrombin/thrombin is upregulated in C3-deficient mice. Liver sections from C3-sufficient (left panels) and (3-deficient (right panels) mice were stained with monoclonal antibodies specific for prothrombin/thrombin (top panels) or isotype control antibodies (bottom panels). Brown staining represents bound antibody. The slides were counterstained with hematoxylin (blue). Original objective: 40x.

\section{Abbreviations}

DMSO: dimethyl sulfoxide; FcyR: Fc receptor for immunoglobulin G; FcRy: the cytoplasmic signaling chain shared by activating $F c$ receptors for immunoglobulin G; GPI: glucose-6-phosphate isomerase; IFNY: interferongamma; IgG: immunoglobulin G; IL-17: interleukin-17; LPS:

lipopolysaccharide; MAC: membrane attack complex; MHC: major histocompatibility complex; NOD: non-obese diabetic; TCR: T-cell receptor; Th17: T helper 17.

\section{Acknowledgements}

The studies were supported by K08 AR054317 from the National Institute of Arthritis and Musculoskeletal and Skin Diseases (to BAB) and by awards and start-up funds from the University of Minnesota Department of Pediatrics. BAB was supported by an Arthritis Foundation Arthritis Investigator Award. The authors thank Sindhuja Rao for technical assistance and Christophe Benoist, Michael Carroll, Diane Mathis, and Brigitta Stockinger for gifts of mice and reagents.

\section{Author details}

${ }^{1}$ Center for Immunology and Department of Pediatrics, University of Minnesota, 2101 6th Street SE, Minneapolis, MN 55414, USA. ${ }^{2}$ Current address: lowa Inflammation Program, University of lowa, 2501 Crosspark Road, D168-MTF, Coralville, IA 52241, USA.

\section{Authors' contributions}

JLA designed and performed experiments, interpreted data, and assisted in writing the manuscript. SSH performed experiments and assisted in writing the manuscript. BAB designed and oversaw experiments, interpreted data, and wrote the manuscript. All authors read and approved the final manuscript.

\section{Competing interests}

The authors declare that they have no competing interests.

Received: 30 October 2012 Revised: 19 November 2012

Accepted: 11 December 2012 Published: 13 December 2012

\section{References}

1. Ravetch JV, Clynes RA: Divergent roles for Fc receptors and complement in vivo. Annu Rev Immunol 1998, 16:421-432

2. Baumann U, Kohl J, Tschernig T, Schwerter-Strumpf K, Verbeek JS, Schmidt RE, Gessner JE: A codominant role of Fc gamma RI/III and C5aR in the reverse Arthus reaction. $J$ Immunol 2000, 164:1065-1070.

3. Sylvestre D, Clynes R, Ma M, Warren H, Carroll MC, Ravetch JV: Immunoglobulin G-mediated inflammatory responses develop normally in complement-deficient mice. J Exp Med 1996, 184:2385-2392.

4. Nimmerjahn F, Ravetch JV: FcgammaRs in health and disease. Curr Top Microbiol Immunol 2011, 350:105-125. 
5. Walport MJ: Complement. Second of two parts. N Engl J Med 2001, 344:1140-1144.

6. Walport MJ: Complement. First of two parts. N Engl J Med 2001, 344:1058-1066.

7. Kitamura H, Matsumoto M, Nagaki K: C3-independent immune haemolysis: haemolysis of EAC140xy2 cells by C5-C9 without participation of C3. Immunology 1984, 53:575-582.

8. Salama A, Bhakdi S, Mueller-Eckhardt C: Evidence suggesting the occurrence of C3-independent intravascular immune hemolysis. Reactive hemolysis in vivo. Transfusion 1987, 27:49-53.

9. Huber-Lang M, Sarma JV, Zetoune FS, Rittirsch D, Neff TA, McGuire SR, Lambris JD, Warner RL, Flierl MA, Hoesel LM, Gebhard F, Younger JG, Drouin SM, Wetsel RA, Ward PA: Generation of C5a in the absence of C3: a new complement activation pathway. Nat Med 2006, 12:682-687.

10. Girardi G, Redecha P, Salmon JE: Heparin prevents antiphospholipid antibody-induced fetal loss by inhibiting complement activation. Nat Med 2004, 10:1222-1226.

11. Yu G, Sun Y, Foerster K, Manuel J, Molina H, Levy GA, Gorczynski RM, Clark DA: LPS-induced murine abortions require $C 5$ but not $C 3$, and are prevented by upregulating expression of the CD200 tolerance signaling molecule. Am J Reprod Immunol 2008, 60:135-140.

12. Amara U, Flierl MA, Rittirsch D, Klos A, Chen H, Acker B, Bruckner UB, Nilsson B, Gebhard F, Lambris JD, Huber-Lang M: Molecular intercommunication between the complement and coagulation systems. $\mathrm{J}$ Immunol 2010, 185:5628-5636.

13. Kumar V, Ali SR, Konrad S, Zwirner J, Verbeek JS, Schmidt RE, Gessner JE: Cell-derived anaphylatoxins as key mediators of antibody-dependent type II autoimmunity in mice. J Clin Invest 2006, 116:512-520.

14. Syed SN, Konrad S, Wiege K, Nieswandt B, Nimmerjahn F, Schmidt RE, Gessner JE: Both FcgammaRIV and FcgammaRIII are essential receptors mediating type II and type III autoimmune responses via FcRgammaLAT-dependent generation of C5a. Eur J Immunol 2009, 39:3343-3356.

15. Baumann U, Chouchakova N, Gewecke B, Kohl J, Carroll MC, Schmidt RE, Gessner JE: Distinct tissue site-specific requirements of mast cells and complement components C3/C5a receptor in IgG immune complexinduced injury of skin and lung. J Immunol 2001, 167:1022-1027.

16. Kouskoff V, Korganow AS, Duchatelle V, Degott C, Benoist C, Mathis D: Organ-specific disease provoked by systemic autoimmunity. Cell 1996, 87:811-822

17. Matsumoto I, Staub A, Benoist C, Mathis D: Arthritis provoked by linked T and B cell recognition of a glycolytic enzyme. Science 1999, 286:1732-1735.

18. Korganow AS, Ji H, Mangialaio S, Duchatelle V, Pelanda R, Martin T, Degott C, Kikutani H, Rajewsky K, Pasquali JL, Benoist C, Mathis D: From systemic $T$ cell self-reactivity to organ-specific autoimmune disease via immunoglobulins. Immunity 1999, 10:451-461.

19. Corr $M$, Crain B: The role of FcgammaR signaling in the $K / B \times N$ serum transfer model of arthritis. J Immunol 2002, 169:6604-6609.

20. Ji H, Ohmura K, Mahmood U, Lee DM, Hofhuis FM, Boackle SA, Takahashi K, Holers VM, Walport M, Gerard C, Ezekowitz A, Carroll MC, Brenner M, Weissleder R, Verbeek JS, Duchatelle V, Degott C, Benoist C, Mathis D: Arthritis critically dependent on innate immune system players. Immunity 2002, 16:157-168.

21. Ji H, Gauguier D, Ohmura K, Gonzalez A, Duchatelle V, Danoy P, Garchon HJ, Degott C, Lathrop M, Benoist C, Mathis D: Genetic influences on the end-stage effector phase of arthritis. J Exp Med 2001, 194:321-330.

22. Binstadt BA, Hebert $J$, Ortiz-Lopez A, Bronson R, Benoist C, Mathis D: The same systemic autoimmune disease provokes arthritis and endocarditis via distinct mechanisms. Proc Natl Acad Sci USA 2009, 106:16758-16763.

23. Wetsel RA, Fleischer DT, Haviland DL: Deficiency of the murine fifth complement component (C5). A 2-base pair gene deletion in a 5'-exon. J Biol Chem 1990, 265:2435-2440.

24. Wessels MR, Butko P, Ma M, Warren HB, Lage AL, Carroll MC: Studies of group $B$ streptococcal infection in mice deficient in complement component C3 or C4 demonstrate an essential role for complement in both innate and acquired immunity. Proc Natl Acad Sci USA 1995, 92:11490-11494

25. Takai T, Li M, Sylvestre D, Clynes R, Ravetch JV: FCR gamma chain deletion results in pleiotrophic effector cell defects. Cell 1994, 76:519-529.
26. Frei $Y$, Lambris JD, Stockinger B: Generation of a monoclonal antibody to mouse C5 application in an ELISA assay for detection of anti-C5 antibodies. Mol Cell Probes 1987, 1:141-149.

27. Schulze EB, Hedley BD, Goodale D, Postenka CO, Al-Katib W, Tuck AB, Chambers AF, Allan AL: The thrombin inhibitor Argatroban reduces breast cancer malignancy and metastasis via osteopontin-dependent and osteopontin-independent mechanisms. Breast Cancer Res Treat 2008, 112:243-254.

28. Asanuma K, Wakabayashi H, Hayashi T, Okuyama N, Seto M, Matsumine A, Kusuzaki K, Suzuki K, Uchida A: Thrombin inhibitor, argatroban, prevents tumor cell migration and bone metastasis. Oncology 2004, 67:166-173.

29. Tsao PY, Arora V, Ji MQ, Wright AC, Eisenberg RA: KRN/I-Ag7 mouse arthritis is independent of complement C3. J Clin Immunol 2011, 31:857-863.

30. Kim TS, Park M, Nepomuceno RR, Palmarini G, Winokur S, Cotman CA, Bengtsson $U$, Tenner AJ: Characterization of the murine homolog of C1qR (P): identical cellular expression pattern, chromosomal location and functional activity of the human and murine C1qR(P). Mol Immunol 2000, 37:377-389.

31. Hashimoto M, Hirota K, Yoshitomi H, Maeda S, Teradaira S, Akizuki S, PrietoMartin P, Nomura T, Sakaguchi N, Kohl J, Heyman B, Takahashi M, Fujita T, Mimori T, Sakaguchi S: Complement drives Th17 cell differentiation and triggers autoimmune arthritis. J Exp Med 2010, 207:1135-1143.

32. Jacobs JP, Wu HJ, Benoist C, Mathis D: IL-17-producing T cells can augment autoantibody-induced arthritis. Proc Natl Acad Sci USA 2009, 106:21789-21794.

33. Wu HJ, Ivanov II, Darce J, Hattori K, Shima T, Umesaki Y, Littman DR, Benoist C, Mathis D: Gut-residing segmented filamentous bacteria drive autoimmune arthritis via T helper 17 cells. Immunity 2010, 32:815-827.

34. Foerster K, He W, Manuel J, Bartczak A, Liu M, Markert UR, Levy GA, Clark DA: LPS-induced occult loss in mice requires FGL2. Am J Reprod Immunol 2007, 58:524-529.

35. Marty I, Peclat V, Kirdaite G, Salvi R, So A, Busso N: Amelioration of collagen-induced arthritis by thrombin inhibition. J Clin Invest 2001, 107:631-640

36. Krisinger MJ, Goebeler V, Lu Z, Meixner SC, Myles T, Pryzdial EL, Conway EM: Thrombin generates previously unidentified $C 5$ products that support the terminal complement activation pathway. Blood 2012, 120:1717-1725.

37. Thiagarajan P, Dannenbring R, Matsuura K, Tramontano A, Gololobov G, Paul S: Monoclonal antibody light chain with prothrombinase activity. Biochemistry 2000, 39:6459-6465.

38. Woodruff TM, Nandakumar KS, Tedesco F: Inhibiting the C5-C5a receptor axis. Mol Immunol 2011, 48:1631-1642

39. Fischetti F, Durigutto P, Macor P, Marzari R, Carretta R, Tedesco F: Selective therapeutic control of $\mathrm{C} 5 \mathrm{a}$ and the terminal complement complex by anti-C5 single-chain Fv in an experimental model of antigen-induced arthritis in rats. Arthritis Rheum 2007, 56:1187-1197.

\section{doi:10.1186/ar4117}

Cite this article as: Auger et al: Autoantibody-mediated arthritis in the absence of C3 and activating Fc $\gamma$ receptors: C5 is activated by the coagulation cascade. Arthritis Research \& Therapy 2012 14:R269.

\section{Submit your next manuscript to BioMed Central and take full advantage of:}

- Convenient online submission

- Thorough peer review

- No space constraints or color figure charges

- Immediate publication on acceptance

- Inclusion in PubMed, CAS, Scopus and Google Scholar

- Research which is freely available for redistribution

Submit your manuscript at www.biomedcentral.com/submit
C Biomed Central 